
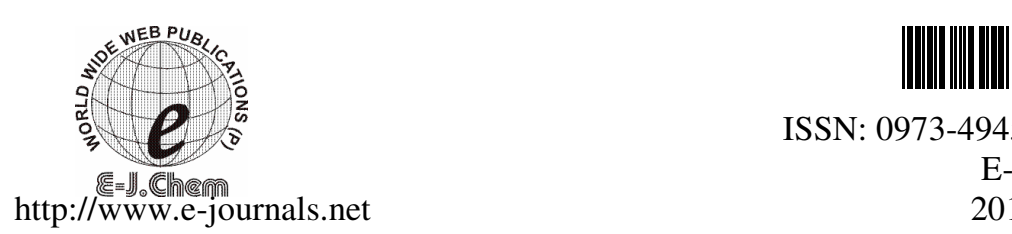

ISSN: 0973-4945; CODEN ECJHAO

E-Journal of Chemistry

2010, 7(S1), S495-S503

\title{
Simultaneous Determination of Paracetamol, Acetyl Salicylic Acid, Mefenamic Acid and Cetirizine Dihydrochloride in the Pharmaceutical Dosage Form
}

\author{
FREDDY H. HAVALDAR* and DHARMENDRA L.VAIRAL
}

\author{
Nadkarny - Sacasa Research Laboratory \\ Department of Chemistry, St.Xavier's College, Mumbai - 400001, India \\ vairal21@yahoo.com
}

Received 27 April 2010; Accepted 20 June 2010

\begin{abstract}
A simple, specific, accurate and economical isocratic reversed phase liquid chromatographic (RP-HPLC) method was developed and subsequently validated for the determination of paracetamol, acetyl salicylic acid, mefenamic acid and cetirizine dihydrochloride. Separation was achieved with a Nucleodur $100 \mathrm{C}-18$ column having $250 \times 4.6 \mathrm{~mm}$ i.d. with $5 \mu \mathrm{m}$ particle size and disodium hydrogen phosphate buffer adjusted to $\mathrm{pH} 6.5$ using diluted orthophosphoric acid and acetonitrile $(60: 40 \mathrm{v} / \mathrm{v})$ as eluent at a constant flow rate of $1.0 \mathrm{~mL}$ per min. UV detection was performed at $220 \mathrm{~nm}$. The retention time of acetyl salicylic acid, paracetamol, mefenamic acid and cetirizine dihydrochloride were $2.01 \mathrm{~min}, 2.92 \mathrm{~min}, 4.91 \mathrm{~min}$ and $10.2 \mathrm{~min}$ respectively. This method is simple, rapid and selective and can be used for routine analysis of analgesic and antipyretic drugs in pharmaceutical formulations. The proposed method was validated and successfully used for estimation of paracetamol, acetyl salicylic acid, mefenamic acid and cetirizine dihydrochloride in the pharmaceutical dosage form.
\end{abstract}

Keywords: Validation, RP-HPLC, Paracetamol, Acetyl salicylic acid, Mefenamic acid (MEF) and Cetirizine dihydrochloride.

\section{Introduction}

Analysis is an integral component of preformulation, formulation and active ingredient drug development research. It is essential to have a validated, stability indicated or specific analytical method of analysis for the drug for which the drug delivery system is to be designed. If a suitable analytical method is not available then it is essential to develop an appropriate simple, specific, accurate and economical analytical method for the selected drug to aid during various steps of formulation design. Reversed phase liquid chromatographic 
(RP-HPLC) technique is one of the latest and most widely applied techniques for drug estimation. Reversed phase liquid chromatographic method is preferred over other techniques for routine analysis of drug as it is less time consuming and also economical. A literature survey regarding quantitative analysis of these drugs revealed that attempts were made to develop analytical methods for paracetamol, acetyl salicylic acid, mefenamic acid and cetirizine dihydrochloride using spectrophotometry ${ }^{1-13}$, $\operatorname{titration}^{14}, \operatorname{HPTLC}^{15}$, disintegration test ${ }^{16}$, dissolution test ${ }^{17}$, FTIR, DSC and XRD ${ }^{18}$, IR and NMR ${ }^{19}$, HPLC $^{20-37}$, $\mathrm{LC}$ - eletrospray ionization $\mathrm{MS}^{38}, \mathrm{LC}-\mathrm{MS} \mathrm{MS}^{39}$ and micellar electrokinetics capillary chromatography ${ }^{40}$. Paracetamol, acetyl salicylic acid, mefenamic acid and cetirizine dihydrochloride is official in pharmacopoeias and HPLC method had been reported for its estimation. This paper describes a new RP- HPLC method for the estimation of paracetamol, acetyl salicylic acid, mefenamic acid and cetirizine dihydrochloride combination in mixture using simple mobile phase. In the present study simple, rapid and selective RP-HPLC method was developed for estimation of paracetamol, acetyl salicylic acid, mefenamic acid and cetirizine dihydrochloride in the pharmaceutical dosage form. Linearity, accuracy, precision, detection limit, quantitation limit and recovery studies were carried out to establish precision. This paper describes the development and validation of the proposed methods.

\section{Experimental}

The liquid chromatographic system consists of the following components: Agilent HPLC model (1100 series) containing quaternary pump, sample thermostat, column thermostat, thermostated autosampler and variable wavelength programmable detector. Chromatographic analysis was performed using Chemstation software on a Nucleodur 100 $\mathrm{C}-18$ column with $250 \times 4.6 \mathrm{~mm}$ i.d. and $5 \mu \mathrm{m}$ particle size. The Metter Telledo electronic balance (AX 105) was used for weighing purpose. Analytically pure paracetamol (lot No. PARA/WS/09/001 Purity >99\%), acetyl salicylic acid, (lot No. ASA/WS/09/001 Purity $>99 \%$ ), mefenamic acid (lot No. MA/WS/09/001 Purity >99\%) and cetirizine dihydrochloride (lot No. CH/WS/09/001 Purity $>99 \%$ ) were obtained as gift samples from Nicholas Piramal India Ltd. Mumbai, India. Acetonitrile, methanol (E.Merck, Mumbai, India), water (TKA water purification system) were of HPLC grade, while orthophosphoric acid and disodium hydrogen phosphate (S.D. Fine Chemicals, Mumbai, India) were of analytical grade used for the preparation of mobile phase. Three commercial formulations each of paracetamol and mefenamic acid (Meftal forte tablets, Blue Cross Laboratories. Mumbai, India), acetyl acetic acid (Ecosprin Tablets, USV Ltd. Mumbai, India) and cetirizine dihydrochloride (Alerid Tablets, Cipla Ltd. Mumbai, India) were selected from local market on random basis.

\section{Preparation of reagent and solution}

A $200 \mu \mathrm{g} / \mathrm{mL}$ stock solution of paracetamol, acetyl salicylic acid, mefenamic acid and cetirizine dihydrochloride were prepared as per the following procedure. Stock solution of paracetamol, acetyl salicylic acid, mefenamic acid and cetirizine dihydrochloride were prepared in water and acetonitrile $(1: 1)$ by first dissolving $50 \mathrm{mg}$ each of the standard sample in $50 \mathrm{~mL}$ water: acetonitrile $(1: 1) .10 \mathrm{~mL}$ of the above solution was pipetted out into $50 \mathrm{~mL}$ volumetric flask and then, making up the final volume with diluent. From the above stock solution, various standard solutions were made to obtain solutions of 100, 150, 200, 250 and $300 \mu \mathrm{g} / \mathrm{mL}$ and their respective absorbance values were measured at fixed wavelength. Average absorbance values, standard deviation and percentage correlation coefficients at each concentration were calculated for each drugs. 


\section{Optimization of experimental condition}

Disodium hydrogen phosphate $\left(\mathrm{Na}_{2} \mathrm{HPO}_{4}\right)$ was weighed $(2.84 \mathrm{~g})$ and dissolved in $1000 \mathrm{~mL}$ water. Finally the pH 6.5 was adjusted with diluted ortho phosphoric acid. The buffer solution was sonicated for about 5 to 10 minutes and filtered using Whatman filter paper (No.1). An isocratic reversed phase C-18 column equilibrated with mobile phase $0.02 \mathrm{mmol}$ disodium hydrogen phosphate-acetonitrile (60:40) was used. Mobile phase composition: 60 volume of buffer and 40 volume of acetonitrile were mixed. Mobile phase flow rate was maintained at $1.0 \mathrm{~mL}$ per min. and effluents were monitored at $220 \mathrm{~nm}$. The sample was injected using a $10 \mu \mathrm{L}$ fixed loop and the total run time was $15 \mathrm{~min}$.

\section{Limit of detection and limit of quantification}

A calibration curve was prepared using concentrations in the range of $0.1-0.3 \mathrm{mg} / \mathrm{mL}$ for paracetamol, acetyl salicylic acid, mefenamic acid and cetirizine dihydrochloride. The standard deviations of $y$-intercepts of regression lines were determined and kept in the following equation for the determination of detection limit and quantitation limit. Detection limit $=3.3 \sigma / \mathrm{s}$; quantitation limit $=10 \sigma / \mathrm{s}$; where in $\sigma$ is standard deviation of $y$-intercepts of regression lines and $\mathrm{s}$ is the slope of the calibration curve. Detection limit and quantitation limit can also be estimated using signal to noise and relative standard deviation method.

\section{Linearity studies}

The content of twenty tablets were taken and weighed. Powder equivalent to $100 \mathrm{mg}$ of paracetamol (PARA), acetyl salicylic acid (ECO), mefenamic acid (MEF) and cetirizine dihydrochloride (CET) respectively were accurately weighed and transferred to four separate $100 \mathrm{~mL}$ volumetric flasks and $50 \mathrm{~mL}$ of diluent was added to the same and the flasks were sonicated for $15.0 \mathrm{~min}$. The flasks were shaken and the volume was diluted up to the mark with the same mixture. The above solutions were filtered using Whatman filter paper (No.1). Appropriate volume of the aliquots of paracetamol, acetyl salicylic acid, mefenamic acid and cetirizine dihydrochloride stock solutions were taken in different $20 \mathrm{~mL}$ volumetric flasks and the volume was made up to the mark with diluent to obtain final concentration of 100, 150, 200, 250 and $300 \mu \mathrm{g} / \mathrm{mL}$ of paracetamol, acetyl salicylic acid, mefenamic acid and cetirizine dihydrochloride respectively. The solutions were sonicated for $5.0 \mathrm{~min}$. The solutions were injected at above chromatographic conditions and peak areas were measured. Calibration curves were constructed by plotting the average peak areas versus concentrations.

\section{Precision and accuracy of method (Recovery studies)}

\section{Paracetamol and Mefenamic acid}

The content of twenty tablets of meftal forte were taken and weighed. Powder equivalent to 100 $\mathrm{mg}$ of paracetamol and mefenamic acid were accurately weighed and transferred to $100 \mathrm{~mL}$ volumetric flask and $50 \mathrm{~mL}$ of diluent was added to the same and the flask was sonicated for 15.0 min. The flask was shaken and the volume was diluted up to the mark with the same mixture. The above solution was filtered using Whatman filter paper (No.1). Appropriate volume of the aliquot of solution was taken to obtain 250,200 and $100 \mu \mathrm{g} / \mathrm{mL}$ of paracetamol and mefenamic acid. The drug content per tablet of the above brand of paracetamol and mefenamic acid were calculated from the absorbance values obtained (by taking average of three determinations).

\section{Acetyl salicylic acid}

The contents of twenty tablets of ecosprin were taken and weighed. Powder equivalent to $100 \mathrm{mg}$ of acetyl salicylic acid was accurately weighed and transferred $100 \mathrm{~mL}$ volumetric flask and $50 \mathrm{~mL}$ of diluent was added to the same and the flask was sonicated for $15.0 \mathrm{~min}$. 
The flask was shaken and the volume was diluted up to the mark with the same mixture. The above solution was filtered using Whatman filter paper (No.1). Appropriate volume of the aliquot of solution was taken to obtain 250,200 and $100 \mu \mathrm{g} / \mathrm{mL}$ of acetyl salicylic acid. The drug content per tablet of the above brand of acetyl salicylic acid was calculated from the absorbance values obtained (taking average of three determinations).

\section{Cetirizine dihydrochloride}

The content of twenty tablets of alerid were taken and weighed. Powder equivalent to $100 \mathrm{mg}$ of cetirizine dihydrochloride was accurately weighed and transferred $100 \mathrm{~mL}$ volumetric flask and $50 \mathrm{~mL}$ of diluent was added to the same and the flask was sonicated for $15.0 \mathrm{~min}$. The flask was shaken and the volume was diluted up to the mark with the same mixture. The above solution was filtered using Whatman filter paper (No.1). Appropriate volume of the aliquot of solution was taken to obtain 250,200 and $100 \mu \mathrm{g} / \mathrm{mL}$ of cetirizine dihydrochloride. The drug content per tablet of the above brand of cetirizine dihydrochloride was calculated from the absorbance values obtained (by taking average of three determinations). The accuracy of the method was determined by calculating recoveries of paracetamol, acetyl salicylic acid, mefenamic acid and cetirizine dihydrochloride using standard solutions.

\section{Results and Discussion}

Optimization of mobile phase or chromatographic condition was performed based on resolution, tailing factor, symmetric factor and peak areas obtained for paracetamol, acetyl salicylic acid, mefenamic acid and cetirizine dihydrochloride are shown in Table 1.

Table 1. Optimization of experimental conditions

\begin{tabular}{ll}
\hline Parameters & Optimized condition \\
\hline Chromatograph & Agilent HPLC \\
Column & Nucleodur $100 \mathrm{C}-18,250 \times 4.6 \mathrm{~mm}, 5 \mu \mathrm{m}$ \\
Mobile phase & $20 \mathrm{mmol} \mathrm{Na}_{2} \mathrm{HPO}_{4} \mathrm{pH}-6.5:$ Acetonitrile $(60: 40 \mathrm{v} / \mathrm{v})$ \\
Flow rate & $1.0 \mathrm{~mL}$ per min. \\
Detection & $\mathrm{UV}$ at $220 \mathrm{~nm}$ \\
Injection volume & $10 \mu \mathrm{L}$ \\
Temperature & Ambient \\
Run Time & $15.0 \mathrm{~min}$. \\
Retention time - ECO & About $2.01 \mathrm{~min}$. \\
Retention time - PARA & About $2.92 \mathrm{~min}$. \\
Retention time - MEF & About $4.91 \mathrm{~min}$. \\
Retention time - CET & About $10.2 \mathrm{~min}$. \\
\hline
\end{tabular}

* Buffer filtered through a $0.45 \mu$ membrane filter (Millipore), degassed and sonicated.

The mobile phase $0.02 \mathrm{mmol}$ disodium hydrogen phosphate adjusted to $\mathrm{pH} 6.5$ using diluted orthophosphoric acid and acetonitrile in the composition (60:40) was found to be satisfactory. The retention time for paracetamol, acetyl salicylic acid, mefenamic acid and cetirizine dihydrochloride were about $2.92 \mathrm{~min}, 2.01 \mathrm{~min}, 4.91$ and $10.2 \mathrm{~min}$. respectively (Figure1).

These mobile phase composition gave symmetric and well resolved peaks for paracetamol, acetyl salicylic acid, mefenamic acid and cetirizine dihydrochloride. Overlain UV spectra of paracetamol-acetyl salicylic acid and mefenamic acid-cetirizine dihydrochloride showed that these drugs absorbs appreciably at $220 \mathrm{~nm}$. Hence $220 \mathrm{~nm}$ was selected as the detection wavelength in the liquid chromatography (Figures $2 \& 3$ ). 


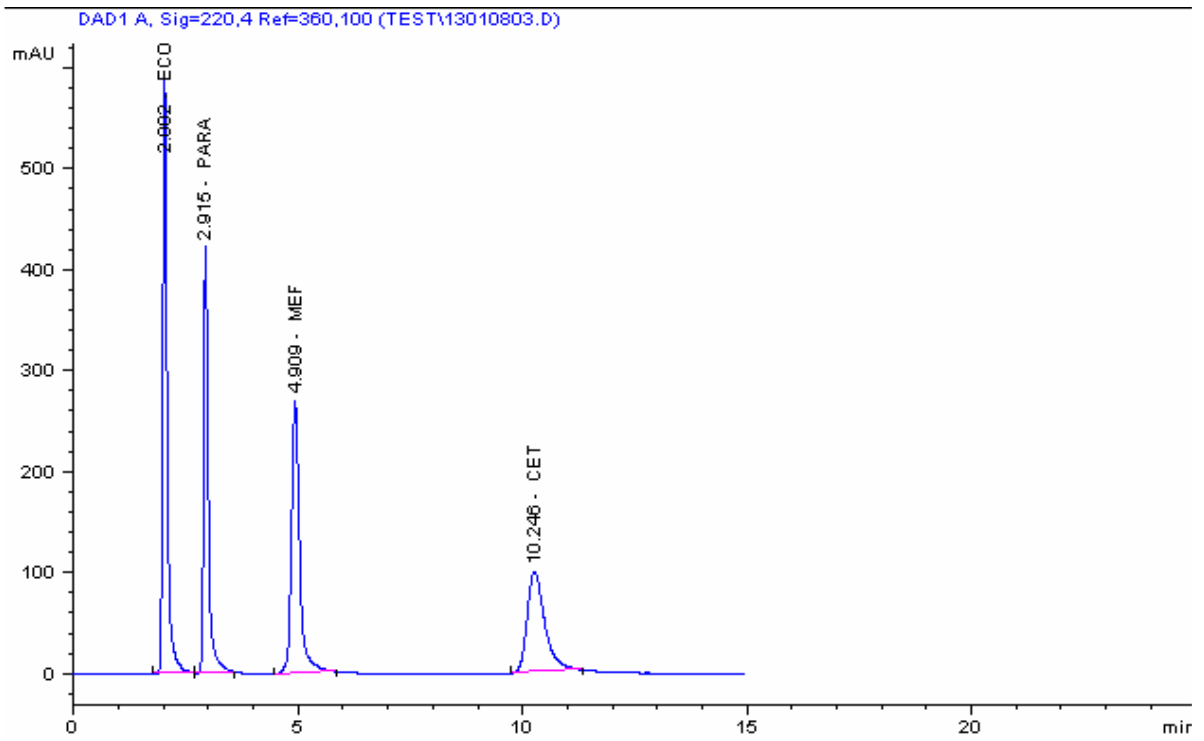

Figure 1. Typical chromatogram of PARA, ECO, MEF and CET (Chromatogram showing well resolved peaks of PARA, ECO, MEF and CET).

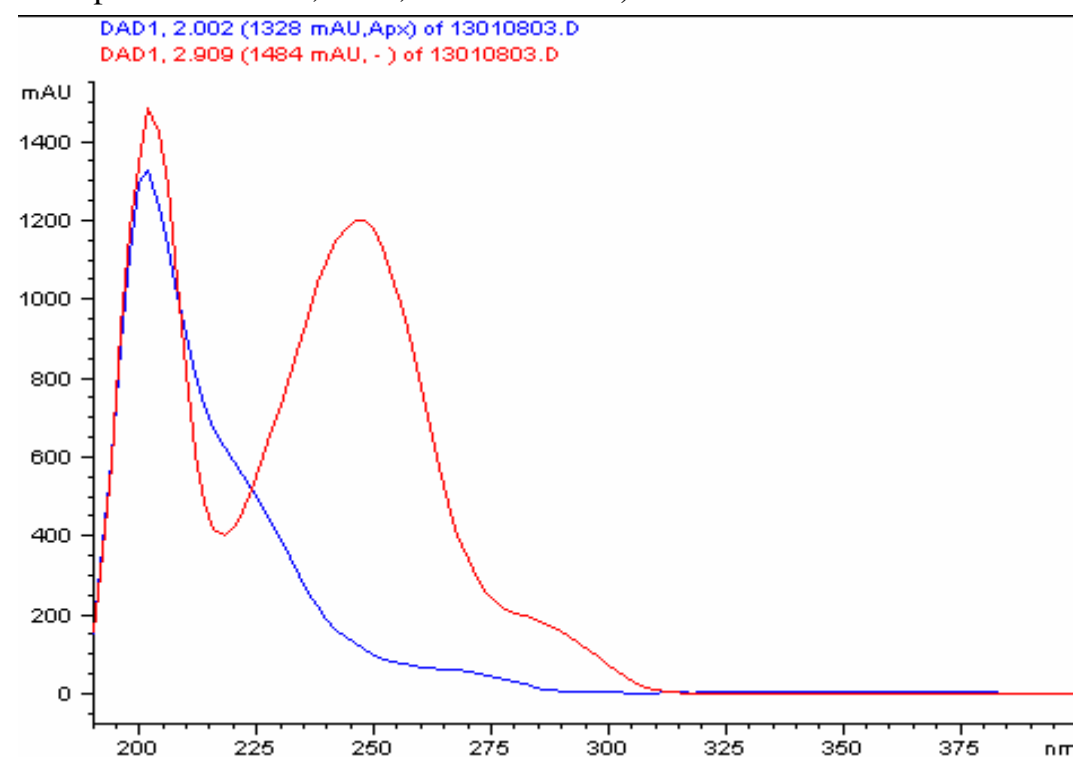

Figure 2. UV overlain spectra of PARA and ECO

The data of regression analysis of the calibration curves are shown in Table 2. The resolution between the acetyl salicylic acid and paracetamol were found 4.68 and resolution between paracetamol and mefenamic acid were found 6.73 , where as resolution between mefenamic acid and cetirizine dihydrochloride were found 9.45 , which indicates good separation of these four compounds. The symmetric factors for paracetamol, acetyl salicylic acid, mefenamic acid and cetirizine dihydrochloride were $0.64,0.77,0.78$ and 0.75 respectively. 


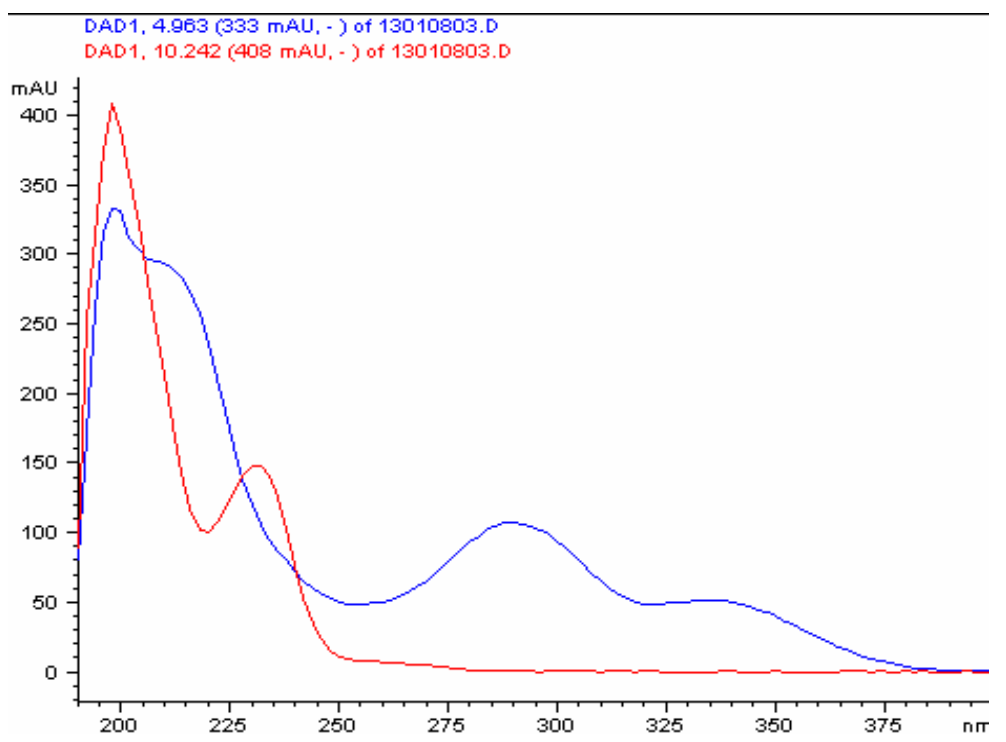

Figure 3. UV overlain spectra of MEF and CET

Table 2. Regression analysis of the calibration curves for the proposed method

\begin{tabular}{lllll}
\hline Parameters & PARA & ECO & MEF & CET \\
\hline Linearity range, $\mu \mathrm{g} / \mathrm{mL}$ & $100-300$ & $100-300$ & $100-300$ & $100-300$ \\
Slope & 772.7 & 1028.4 & 866.4 & 730.3 \\
Intercept & 783.2 & 1036.8 & 830.2 & 590.1 \\
Standard deviation of slope & 81547.3 & 108536 & 91465.5 & 77165.1 \\
Regression $\left(\mathrm{R}^{2}\right)$ & 0.999 & 1.000 & 0.999 & 0.999 \\
\hline
\end{tabular}

The detection limit for paracetamol was $0.39 \mu \mathrm{g} / \mathrm{mL}$ and the quantification limit was 1.2 $\mu \mathrm{g} / \mathrm{mL}$. The detection limit for acetyl salicylic acid and mefenamic acid were $0.39 \mu \mathrm{g} / \mathrm{mL}$ and the quantification limits were $1.2 \mu \mathrm{g} / \mathrm{mL}$. Similarly the detection limit for cetirizine dihydrochloride was $0.37 \mu \mathrm{g} / \mathrm{mL}$ and the quantification limit was $1.1 \mu \mathrm{g} / \mathrm{mL}$, which suggest that these compounds can be estimated accurately. The system suitability parameters are summarized in Table 3. The linearity or calibration curves for paracetamol, acetyl salicylic acid, mefenamic acid and cetirizine dihydrochloride were obtained by plotting the average peak areas of paracetamol, acetyl salicylic acid, mefenamic acid and cetirizine dihydrochloride versus concentrations over a range of $100,150,200,250$ and $300 \mu \mathrm{g} / \mathrm{mL}$ of paracetamol, acetyl salicylic acid, mefenamic acid and cetirizine dihydrochloride respectively shown in Table 4.

Table 3. System suitability parameter

\begin{tabular}{lcccc}
\hline Parameters & PARA & ECO & MEF & CET \\
\hline Linearity range, $\mu \mathrm{g} / \mathrm{mL}$ & $100-300$ & $100-300$ & $100-300$ & $100-300$ \\
Correlation coefficient $(\mathrm{r})$ & 1.000 & 1.000 & 0.999 & 0.999 \\
Theoretical plates $(m e t e r)$ & 13319 & 6716 & 13212 & 11062 \\
Resolution & 4.68 & - & 6.73 & 9.45 \\
Tailing factor & 1.67 & 1.33 & 1.31 & 1.40 \\
Symmetry factor & 0.64 & 0.77 & 0.78 & 0.75 \\
Detection limit, $\mu \mathrm{g} / \mathrm{mL}$ & 0.39 & 0.39 & 0.39 & 0.397 \\
Quantification limit, $\mu \mathrm{g} / \mathrm{mL}$ & 1.2 & 1.2 & 1.2 & 1.1 \\
\hline
\end{tabular}


Table 4. Linearity or calibration curves

\begin{tabular}{cccccccc}
\hline \multicolumn{2}{c}{ PARA } & \multicolumn{2}{c}{ ECO } & \multicolumn{2}{c}{ MEF } & \multicolumn{2}{c}{ CET } \\
\hline $\begin{array}{c}\text { Conc } \\
\text { ppm }\end{array}$ & Av.Area & $\begin{array}{c}\text { Conc, } \\
\text { ppm }\end{array}$ & Av.Area & $\begin{array}{c}\text { Conc, } \\
\text { ppm }\end{array}$ & Av.Area & $\begin{array}{c}\text { Conc, } \\
\text { ppm }\end{array}$ & Av.Area \\
100 & 1555.4 & 100 & 2063.1 & 100 & 1720.2 & 100 & 1357.4 \\
500 & 2316.9 & 150 & 3084.9 & 150 & 2517.4 & 150 & 2023.9 \\
200 & 3114.6 & 200 & 4138.8 & 200 & 3427.2 & 200 & 2730.0 \\
250 & 3884.6 & 250 & 5151.8 & 250 & 4342.1 & 250 & 3545.6 \\
300 & 4635.0 & 300 & 6171.8 & 300 & 5139.8 & 300 & 4248.0 \\
\hline
\end{tabular}

Paracetamol was found to be linear with correlation coefficient $(r)=1.000$. Similarly the calibration curves for acetyl salicylic acid, mefenamic acid and cetirizine dihydrochloride were found to be linear with correlation coefficient $\quad(r)=1.000,0.999$ and 0.999 respectively (Figures 4-7). The recovery study of paracetamol was found in the range of $99.3 \%$ to $99.5 \%$. Acetyl salicylic acid was found in the range of $100.0 \%$ to $100.4 \%$, mefenamic acid was found in the range of $99.7 \%$ to $102.2 \%$ and cetirizine dihydrochloride was found in the range of $100.5 \%$ to $102.5 \%$ respectively. The recovery of paracetamol was found in tablets in the range of $446.9 \mathrm{mg}$ to $447.8 \mathrm{mg}$. The recovery of acetyl salicylic acid was found in the range of $325.0 \mathrm{mg}$ to $326.3 \mathrm{mg}$.

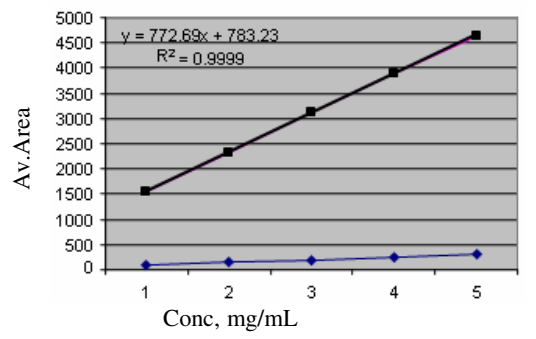

Figure 4. Calibration curve of PARA (Correlation coefficient (r): 1.000)

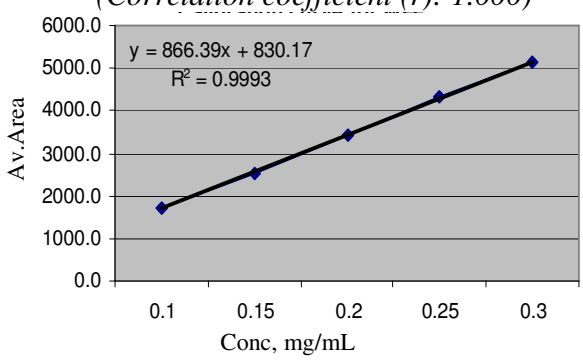

Figure 6. Calibration curve of MEF (Correlation coefficient $(r)=0.999)$

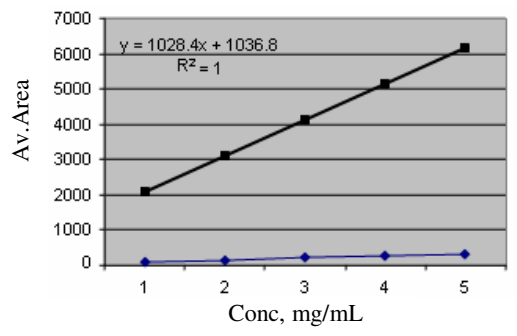

Figure 5. Calibration curve of ECO

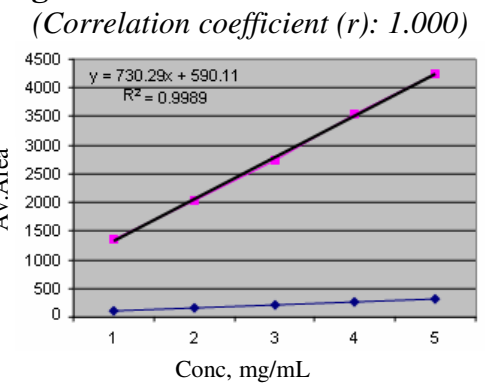

Figure 7. Calibration curve of CET (Correlation coefficient $(r)=0.999$ )

The recovery of mefenamic acid was found in the range of $498.5 \mathrm{mg}$ to $511.0 \mathrm{mg}$ and cetirizine dihydrochloride was found in the range of $10.05 \mathrm{mg}$ to $10.25 \mathrm{mg}$. The chromatographic method was applied to the determination of paracetamol, acetyl salicylic acid, mefenamic acid and cetirizine dihydrochloride in their pharmaceutical dosage form. The results for paracetamol, acetyl salicylic acid, mefenamic acid and cetirizine dihydrochloride were comparable with their corresponding labeled amounts are shown in Table 5. 
Table 5. Assay of combined dosage form and recovery studies

\begin{tabular}{ccccc}
\hline Drugs & Level & $\begin{array}{c}\text { Average assay } \\
\text { Recovery, } \%\end{array}$ & $\begin{array}{c}\text { Amount obtained } \\
\text { mg per tablets }\end{array}$ & $\begin{array}{c}\text { Labeled amount } \\
\text { mg per tablets }\end{array}$ \\
\hline PARA & I & 99.4 & 447.3 & 450.0 \\
& II & 99.3 & 446.9 & \\
ECO & III & 99.5 & 447.8 & 325.0 \\
& I & 100.2 & 325.7 & \\
& II & 100.0 & 325.0 & 500.0 \\
MEF & III & 100.4 & 326.3 & \\
& I & 100.1 & 500.5 & 10.0 \\
& II & 102.2 & 511.0 & \\
CET & III & 99.7 & 498.5 & \\
& I & 100.5 & 10.05 & \\
& II & 101.9 & 10.19 & \\
\hline
\end{tabular}

\section{Conclusion}

We have successfully developed a new RP-HPLC method for the determination of paracetamol, acetyl salicylic acid, mefenamic acid and cetirizine dihydrochloride were found to be simple, economical and useful with high accuracy, precision and low detection limit and quantitation limit. Rapidity and capability of quantifying very low concentration of respective drugs, made them useful for variety of analyses, including pure drug analysis, assay of formulations and stability studies analysis. The proposed methods did not utilize any extraction step for recovering the drug from the formulation excipient matrixes and their by decreased the degree of error, time in estimation of drugs and the overall cost of the analysis. The solvent system used were simple mobile phase with low buffer concentration compared to the reported method. The method gives good resolution between paracetamol, acetyl salicylic acid, mefenamic acid and cetirizine dihydrochloride with a short analysis time (less than 15 minutes). The method was validated and found to be simple, sensitive, accurate, precise and economical. Percentage of assay recovery shows that the method is free from interference of the excipients used in the formulation. Therefore, the proposed method used for routine analysis of paracetamol, acetyl salicylic acid, mefenamic acid and cetirizine dihydrochloride in their pharmaceutical dosage form.

\section{Acknowledgment}

I thank my friend Mr.Haresh Gurav (M/s Nicholas Piramal India Limited, Mumbai) for providing me the gift samples of paracetamol, acetyl salicylic acid, mefenamic acid and cetirizine dihydrochloride. We also like to thanks Ms..Sushma for providing technical assistance.

\section{References}

1. Ali Reza Zarei, Abbas Afkhami and Nahid Sarlak, J AOAC Int., 2005, 88(6), 1695-1701.

2. Drozd J, Hopkala H, Misztal G and Paw B, Acta Pol Pharma., 2002, 59, 3.

3. Ines Toral M, Nelson Lara, Pablo Richter, Andres Tassara, Tapia A E and Cladio Rodriguez, J AOAC Int., 2001, 84, 1.

4. Erdal Dinc, Abdil Ozdemir and Dumitru Baleanu, J Pharm Biomed Anal., 2005, 37(3), 569.

5. Sharma S C, Saxena R C and Talwar S K, Indian J Pharm Sci., 1990, 52(2), 103-107.

6. Srinivasan K K, Alex J, Shirwaikar A A, Jacob S, Sunil Kumar M R, Prabu S L. Indian J Pharm Sci., 2007, 69(4), 540-545.

7. Garg G, Saraf Swarnlata and Saraf S, Indian J Pharm Sci., 2007, 69, 279-281.

8. Mahaparale P R, Sangshetti J N and Kuchekar B S, Indian J Pharm Sci., 2007, 69, 289-292.

9. Mishra P and Dolly Archana, Indian J Pharm Sci., 2006, 68(3), 365-368. 
10. Aditya N, Arora R K and Tiwari Meena, Indian J Pharm Sci., 2006, 68(3), 370-373.

11. Nagulwar Vaishali, Dhurvey Y R, Deshpande Shilpa, Upadhye Kanchan, Bakhle Suparna and Wadetwar Rita, Indian J Pharm Sci., 2006, 68(5), 639-640.

12. Bhatia M S, Kaskhedikar S G and Chaturvedi S C, Indian J Pharm Sci., 1997, 59(2), 45-48.

13. Dhake A S, Sonaje D B, Kasture V S, Nikam P T and Talekar R S, Indian J Pharm Sci., 1994, 56(1), 55-57.

14. Vyas P N and Kharat R B, Indian J Pharm Sci., 1988, 50(5), 279-281.

15. Gandhimathi M, Ravi T K, Shukla Nilima and Sowmiya G, Indian J Pharm Sci., 2007, 69(1), 145-147.

16. Okor R S, Eichie F E, Uhumwangho M U and Aka-Aha A P, Indian J Pharm Sci., 2007, 69(4), 591-594.

17. Xue Zhu Liu, Shu Seng Liu, Jin Feng Wu and Zhao Lun Fang, J Chromatogr B., 1999, 392(2-3), 273-281.

18. Shivakumar H G and Ramalingaraju G, Indian J Pharm Sci., 1999, 61, 100.

19. Biyani M R and Velingkar V S, Indian J Pharm Sci., 2004, 66(6), 822-826.

20. Jelinska A, Stanisz B, Zajac M, Musial W and Ostrowicz A, Acta Pol Pharma., 2000, 57, 171.

21. Ramos Martos N, Aquirre Gomez F, Molina Diaz A and Capitan Vallvey L F, $J$ AOAC Int., 2001, 84(3), 676-683.

22. Senyuva H and Ozden T, J Chromatogr Sci., 2002, 40(2), 97-100.

23. Rao R N and Narasaraju A, Anal Sci., 2006, 22(2), 287-292.

24. Monser L and Darghouth F, J Pharma Biomed Anal., 2002, 27, 851-860.

25. McEvoy E, Donegan S, Power J and Altria K, J Pharma Biomed Anal., 2007, 44(1), 137-143

26. Martin A, Garcia E, Garcia A and Barbas C, J Pharma Biomed Anal., 2002, 29(4), 701-714.

27. Mohammed Shahid Ali, Syed Rafiuddin, Mohsin Ghori and Aamer Roshanali Kahtri, J AOAC Int., 2007, 90(1), 82

28. Natividad Ramos Martos, Francisco Aguirre Gomez, Antonio Molina Diaz and Luis F.Capitan Vallvey, J AOAC Int., 2001, 84(3), 676.

29. Lisiane Bajerski, Simone G Cardoso, Isabel Fracao Diefenbach, Marcelo Donadel Malesuik and Silvia Helena Miollo Borgmann, J AOAC Int., 2005, 88(2), 424-427.

30. Gandhimathi M and Ravi T K, Indian J Pharm Sci., 2007, 69, 123-125.

31. Gopinath R, Rajan S, Meyyanathan SN, Krishnaveni N and Suresh B, Indian J Pharm Sci., 2007, 69, 137-140.

32. Karthik A, Subramanian G, Kumar A Ranjith and Udupa N, Indian J Pharm Sci., 2007, 69(1), 142-144.

33. Anandakumar K, Ayyappan T, Raghu Raman V, Vetrichelvan T, Sankar A S K and Nagavalli D, Indian J Pharm Sci., 2007, 69(1), 597-599.

34. Momin M Y, Yeole P G, Puranik M P and Wadher S J, Indian J Pharm Sci., 2006, 68(3), 387-389.

35. Bhavsar A S, Talele G S, Fursule R Aand Surana S J, Indian J Pharm Sci., 2006, 68(5), 675.

36 Subramaniam G, Shetty R, Agarwal S, Pandey S and Udupa N, Indian J Pharm Sci.,. 2005, 67(2), 247-249.

37. Subramanian G, Vasudevan M, Ravishankar S and Suresh B, Indian J Pharm Sci., 2005, 67(2), 260-263.

38. Pirker R, Huk C W, Popp M and Bonn G K, J Chromatogr B, 2004, 809, 257-264.

39. Ming Ma, Fang Feng, Yulan Sheng, Shuangjin Cui and Han Liu, J Chromatogr B, 2007, 846(1-2), 105-111

40. Deniz Emre and Nuran Ozalti, J Chromatogr B, 2007, 847(2), 126-132. 


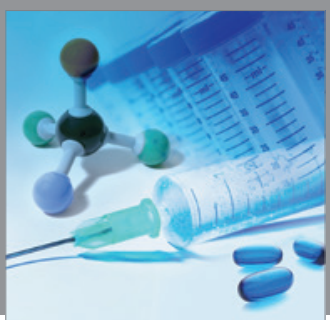

International Journal of

Medicinal Chemistry

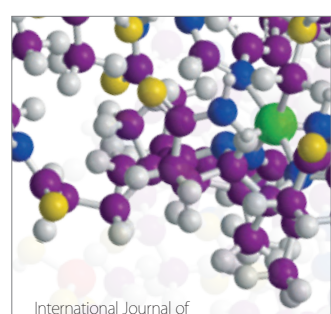

Carbohydrate Chemistry

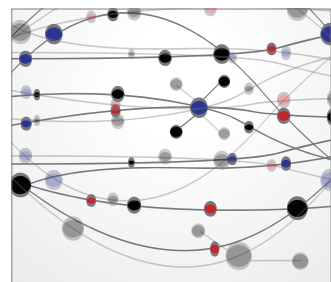

The Scientific World Journal
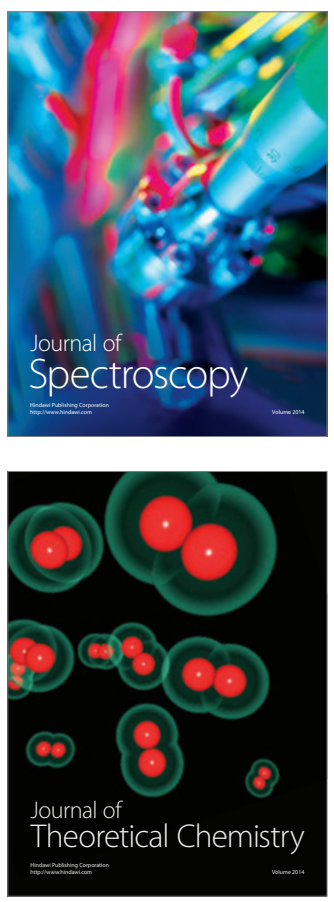
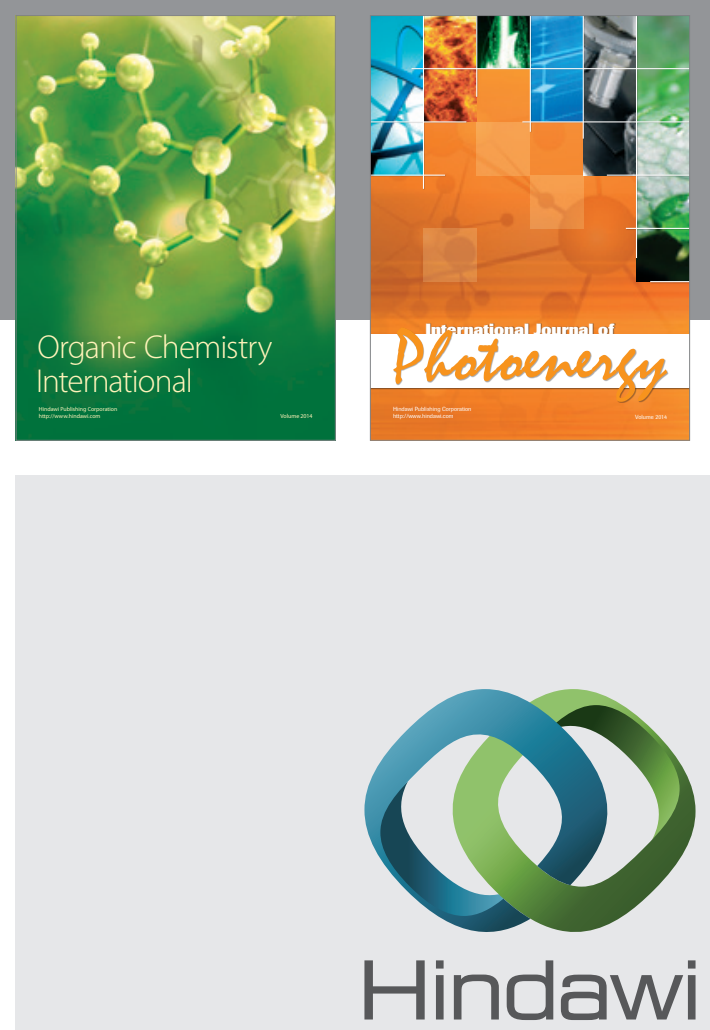

Submit your manuscripts at

http://www.hindawi.com
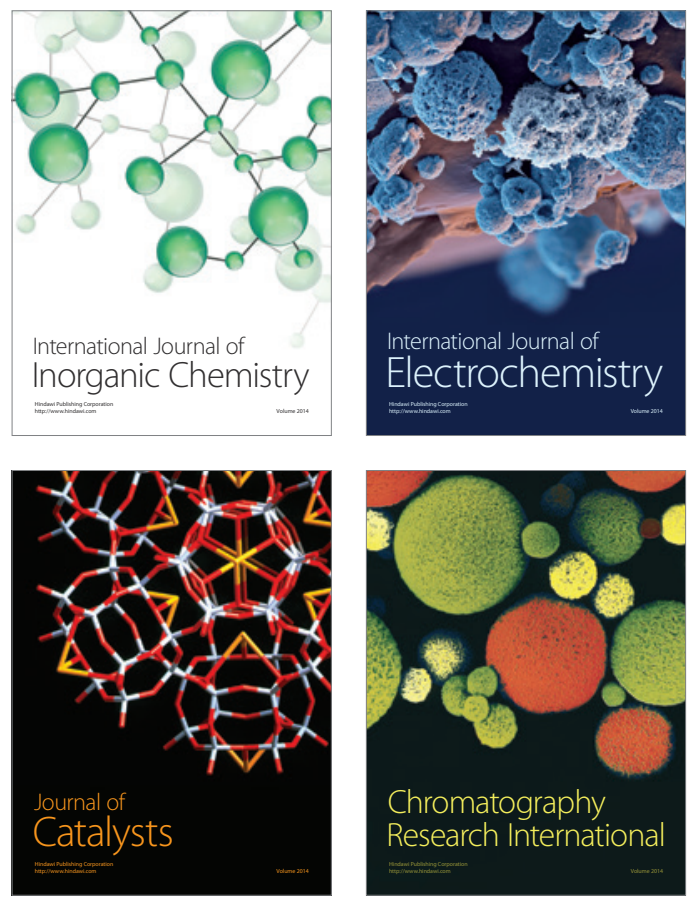
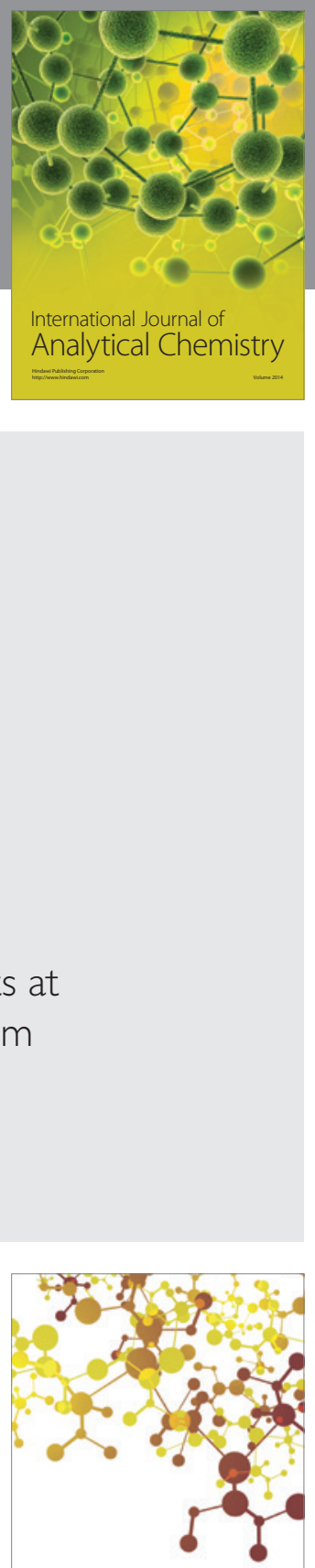

Journal of

Applied Chemistry
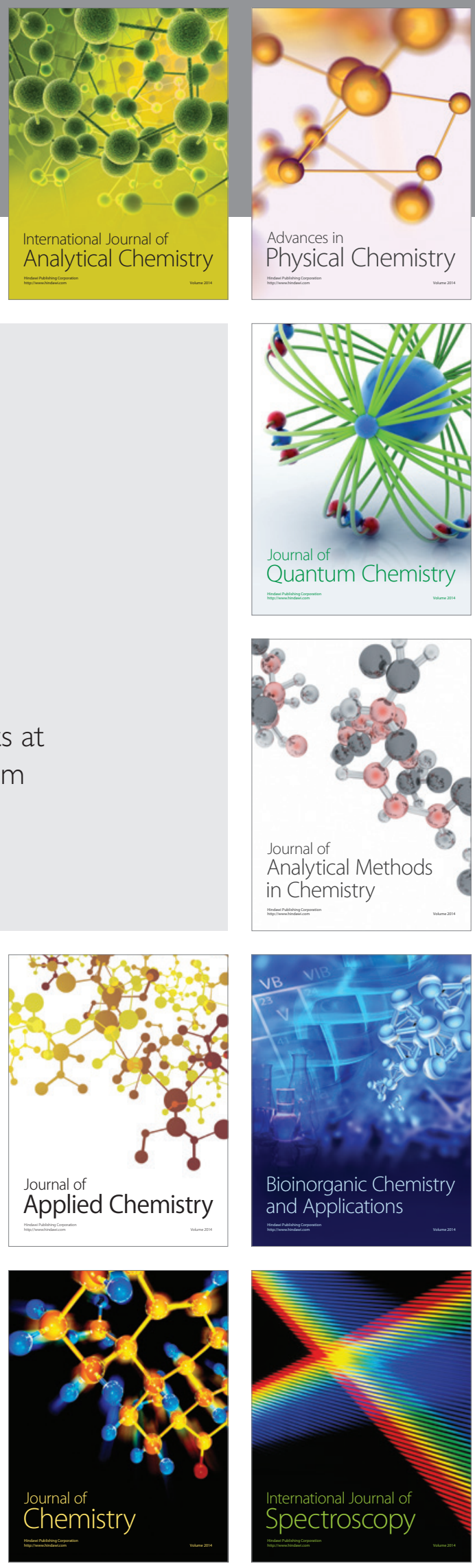